\title{
REVISTAMARACANAN
}

Artigo

\section{Oposicionistas, vagas do terço e eleições parlamentares: 0 caso das disputas para o cargo de deputado federal no Paraná (1915-1918)}

Oppositionists, vacancies of one third and parliamentary elections: the case of the disputes for the position of federal deputy in Paraná (1915-1918)

Sandro Aramis Richter Gomes* Universidade Federal do Paraná, Brasil

Recebido em: 11 mar. 2019.

Aprovado em: 4 maio 2019.

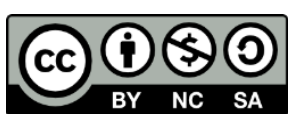

\footnotetext{
* Pesquisador em Estágio de Pós-doutorado no Programa de Pós-graduação em História da Universidade Federal do Paraná. Doutor, Mestre e graduado em História pela Universidade Federal do Paraná. (argomes8@gmail.com) 


\title{
Resumo
}

O presente artigo comporta uma investigação a respeito das campanhas e do desempenho eleitoral de candidatos de oposição ao cargo de deputado federal pelo Estado do Paraná nos anos de 1915 e 1918. Por meio de um estudo de caso, a presente análise objetiva produzir um conhecimento sobre a natureza e os impactos das estratégias eleitorais de oposicionistas em um contexto marcado pela efêmera duração e baixa institucionalidade de partidos de oposição nesse estado. Nesse quadro, há três argumentos fundamentais sustentados neste artigo. O primeiro argumento afirma que, no Paraná dos anos 1910, a oposição ao partido situacionista era liderada por egressos do núcleo político governista. O segundo argumento ressalta que os êxitos eleitorais da oposição paranaense eram derivados do não preenchimento, pelos governistas, de uma chapa completa de candidatos a deputado federal. O terceiro argumento, por fim, afirma que uma semelhança entre a vida político-eleitoral do Paraná e a dos estados que também possuíam distrito eleitoral único era o fato de que, nos anos 1910, as oposições não possuíam base eleitoral para lançar chapas completas de candidatos a deputado federal. Nesse âmbito, este artigo classifica a elite politica paranaense dos anos 1910 como uma "oligarquia competitiva", cujos conflitos internos geraram a polarização partidária no estado.

Palavras-chave: Eleições Parlamentares. Elites Políticas. Estado do Paraná. Partidos de Oposição. Primeira República.

\begin{abstract}
This article contains an investigation about the campaigns and electoral performance of opposition candidates for the position of federal deputy by the State of Paraná in the years 1915 and 1918. Through a case study, the present analysis aims to produce knowledge about the nature and impacts of oppositionist electoral strategies in a context characterized by the ephemeral duration and of parties of opposition in that State. There are three fundamental arguments supported in this article. At that time, therefore, the political clashes in that state were carried out by veteran politicians who, at early of the First Republic, had integrated the party of the government. The second argument affirms that the electoral victories of the opposition were derived from the government's not filling in a complete plaque of candidates for federal deputy. The third argument finally states that a similarity between political-electoral life in Paraná and that of states that also had a single electoral district was the fact that, in the 1910s, the opposition did not have the electoral base to ambition the integral control of the vacancies of federal deputy. In this context, this article classifies the political elite of the $1910 \mathrm{~s}$ as a "competitive oligarchy", whose internal conflicts propitiated party polarization in the state.
\end{abstract}

Keywords: First Brazilian Republic. Opposition Parties. Parliamentary Elections. Political Elites. State of Paraná. 


\section{Introdução}

Neste artigo é empreendida uma investigação acerca das campanhas e do desempenho eleitoral de candidatos de oposição ao cargo de deputado federal pelo Estado do Paraná nos anos de 1915 e 1918. Esse recorte temporal é referente à época em que houve a abertura de uma dissidência no partido governista do Paraná. Nessa oportunidade, ocorreu a formação de uma agremiação oposicionista liderada por políticos veteranos que se afastaram do partido predominante.

O objetivo desta análise é a produção de um conhecimento sobre a natureza e os efeitos das estratégias eleitorais adotadas por adversários de um partido governista em um contexto marcado pela curta duração de agremiações de oposição no Paraná. Em um sentido amplo, o estudo aqui desenvolvido busca avançar no entendimento sobre as condições de êxito eleitoral e formas de organização interna de grupos de oposição que existiram nos estados brasileiros durante a Primeira República.

Há neste estudo a sustentação de três argumentos. O primeiro argumento contém a afirmação de que os próceres da oposição no Paraná eram antigos membros do partido governista existente no estado. Trata-se de evidenciar que, naquele contexto, a formação de partidos de oposição no Paraná era operacional para situacionistas decaídos conseguirem permanecer politicamente ativos. Nesse quadro, o pertencimento a agremiações de oposição era um refúgio para que egressos do grupo político governista conseguissem conservar o seu pertencimento ao jogo político estadual. Contudo, eram pouco duradouros os partidos e as alianças eleitorais constituídas entre aqueles egressos. As tentativas de se reabilitarem na vida política estadual por meio do pertencimento à oposição não foram marcadas pelo esforço de formar partidos dotados de sólida organização interna.

O segundo argumento consiste na afirmação de que eram episódicos os sucessos eleitorais da oposição paranaense. Nesse particular, cumpre demonstrar que os momentos em que os oposicionistas conseguiram eleger seus candidatos a deputado federal foram aqueles nos quais os situacionistas apresentaram chapas incompletas de candidatos. Cumpre, portanto, reconhecer que a presença de oposicionistas paranaenses na Câmara dos Deputados, ao tempo da Primeira República, era decorrente de uma concessão dos situacionistas. Realizada de forma ocasional, essa concessão consistia em facultar um terço das vagas em disputa à oposição. Nessa época, um terço das vagas na bancada paranaense na Câmara significava uma cadeira.

O terceiro argumento salienta que havia uma convergência entre os aspectos da vida política paranaense e a vida política de estados que também possuíam apenas um distrito eleitoral. Um dos aspectos dessa convergência dizia respeito ao fato de que os antagonistas dos partidos situacionistas não costumavam lançar chapas completas a deputado federal. Era pouco frequente a tentativa, pelos contendores do governismo, de suplantar por completo as 
candidaturas oficiais. Outro elemento dessa convergência residia no fato de que, no período em tela, os oposicionistas não representavam uma ameaça ao êxito eleitoral dos governistas. Em estados tais como o Paraná, a oposição necessitava da abertura da vaga do terço para que pudesse experimentar um êxito eleitoral.

A demonstração de tais argumentos permite avançar no entendimento das limitações das oposições estaduais no que concerne à capacidade de constituírem alianças eleitorais e organizarem agremiações partidárias. Ao mesmo tempo, o emprego do método comparativo surge como elemento essencial para salientar que os fenômenos da vida politica paranaense do fim dos anos 1910 eram análogos àqueles existentes nos estados que compunham as pequenas bancadas da Câmara dos Deputados.

A historiografia tem avançado no entendimento sobre as formas de competição eleitoral no Brasil da Primeira República. Em grande medida, tais avanços decorrem do reconhecimento da permanente disposição das oposições estaduais para contestarem as vitórias eleitorais dos candidatos oposicionistas ao Congresso Nacional. As inovações na compreensão sobre a competição político-partidária nos primórdios do Brasil republicano também derivam da identificação do modo de envolvimento de comissões desse Congresso na mediação das contendas eleitorais surgidas nos estados. ${ }^{1}$

De outra parte, a historiografia permanece carente de análises acerca das variações do desempenho eleitoral e dos modos de funcionamento de partidos estaduais. Há restritos avanços na compreensão da vida interna das agremiações partidárias. Permanece episódica a produção de estudos referentes à formação dos quadros dos partidos estaduais e nacionais existentes no Brasil da Primeira República. Nota-se, também, um limitado avanço no conhecimento dos fatores que geravam a desagregação desses quadros. ${ }^{2}$

Comumente, os estudos sobre as alianças eleitorais concebidas por integrantes de elites estaduais são aqueles que comportam informações mais decisivas acerca das relações de força internas aos partidos existentes durante a Primeira República. ${ }^{3}$ Tal cenário impõe obstáculos

\footnotetext{
${ }^{1}$ FIGUEIREDO, Vítor Fonseca. Voto e competição política na Primeira República: o caso de Minas Gerais. 2016. Tese (Doutorado em História) - Instituto de Ciências Humanas, Universidade Federal de Juiz de Fora, Juiz de Fora; RICCI, Paolo; ZULINI, Jaqueline Porto. As eleições no Brasil republicano: para além do estereótipo da fraude eleitoral. História (São Paulo), Franca, v. 63, p. 48-58, 2015.

2 ANTONACCI, Maria Antonieta. RS, as oposições e a Revolução de 23. Porto Alegre: Mercado Aberto, 1981; CASALECCHI, José Ênio. O Partido Republicano Paulista: política e poder (1889-1926). São Paulo: Brasiliense, 1987; DANTAS, José Ibarê. Os partidos políticos em Sergipe, 1889-1964. Rio de Janeiro: Tempo Brasileiro, 1989; MONTENEGRO, Abelardo. Os partidos políticos no Ceará. Fortaleza: Ed. da UFC, 1980; PRADO, Maria Lígia Coelho. A democracia ilustrada: o Partido Democrático de São Paulo, 19261934. São Paulo: Ática, 1986; RESENDE, Maria Lage de. Formação da Estrutura de Dominação em Minas Gerais: o novo PRM (1889-1906). Belo Horizonte: Ed. da UFMG/Proed, 1982; WITTER, José Sebastião. O Partido Republicano Federal (1893-1897). São Paulo: Brasiliense, 1986.

${ }^{3}$ PINTO, Surama Conde Sá. Só para iniciados: o jogo político na antiga capital federal. Rio de Janeiro: Mauad, 2011; VISCARDI, Cláudia Maria Ribeiro. O Teatro das Oligarquias: uma revisão da política do "café com leite". Belo Horizonte: Fino Traço, 2012.
} 
para o conhecimento sobre as diferenças regionais que existiram nas formas de os oposicionistas se defrontarem com os partidos situacionistas.

Mais especificamente, há limitado conhecimento a respeito da composição social, do desempenho eleitoral e das estratégias de ação política das agremiações oposicionistas criadas naquele período. Desse modo, permanece em estágio incipiente o estudo sobre a construção e o declínio dos partidos de oposição no Brasil das primeiras décadas do século XX. Por consequência, mantém-se pouco desenvolvida a análise concernente à relação entre o desempenho eleitoral das oposições estaduais e as formas de organização interna dos partidos nos quais estavam reunidas.

De sua parte, a historiografia atinente ao Paraná não é caracterizada pela produção de análises acerca da organização interna e desempenho eleitoral de partidos estaduais. Há, em verdade, circunstanciais avanços na compreensão sobre o funcionamento de instituições parlamentares e os percursos de membros da elite política estadual. ${ }^{4}$ Entretanto, permanece pouco evidenciada a ligação entre os fenômenos da vida partidária paranaense e a dinâmica político-partidária de outros estados brasileiros. No presente trabalho, convém reconhecer tal conexão a partir do estudo de resultados de eleições ocorridas em estados compostos à época por apenas um distrito eleitoral.

Ao mesmo tempo, compete destacar que os estudos sobre a Primeira República têm avançado no entendimento de temas tais como os padrões de carreiras de parlamentares e a profissionalização da atividade política. ${ }^{5}$ Verifica-se, portanto, que há recentes avanços no entendimento sobre o processo de recrutamento de membros da classe política na mencionada época. O estudo sobre tal processo é decisivo para o reconhecimento das formas mais convencionais de acesso e mobilidade na carreira política. Nesse âmbito, o presente artigo é orientado pelo propósito de salientar uma aproximação entre os indivíduos que lideraram a oposição paranaense no Paraná do fim dos anos 1910. Cumpre destacar, assim, a existência de semelhanças quanto às formas de ascensão e ocaso das carreiras dos oposicionistas que se lançaram candidatos a deputado federal no Paraná nos anos de 1915 e 1918.

Este artigo emprega a categoria de oligarquia competitiva, oriunda dos estudos de Robert Dahl, para formular uma compreensão sobre a natureza da ação política da elite política do Paraná dos anos $1910 .^{6}$ A mobilização de tal categoria permite evidenciar que, no período em

\footnotetext{
${ }^{4}$ GOULART, Mônica Helena Harrich Silva. Classe dominante e jogo político na Assembleia Legislativa Paranaense (1889-1930). 2008. Tese (Doutorado em Sociologia) - Setor de Ciências Humanas, Letras e Artes, Universidade Federal do Paraná, Curitiba.

${ }^{5}$ MASSIMO, Lucas. A profissionalização da oligarquia no Brasil: um estudo sobre a estrutura da carreira política de senadores na Primeira República. 2018. Tese (Doutorado em Ciência Política) - Setor de Ciências Humanas, Letras e Artes, Universidade Federal do Paraná, Curitiba.

${ }^{6}$ A oligarquia competitiva, tal como apresentada na Poliarquia de Robert Dahl, é inerente a um cenário de restrita competição política. Em suma, essa categoria é alusiva a um modelo de vida política anterior ao surgimento das formas mais pluralistas de disputas partidárias. Ver: DAHL, Robert. Poliarquia. Trad.: Celso Mauro Paciornik. São Paulo: Edusp, 1997. Acerca do emprego de tal categoria para o caso da política brasileira da Primeira República, ver: COSTA, Luiz Domingos; MASSIMO, Lucas; PERISSINOTTO, Renato Monsseff. Oligarquia Competitiva e Profissionalização Política: O Caso dos Senadores Brasileiros na Primeira República (1889-1934). Dados, Rio de Janeiro, v. 60, n. 1, p. 79-110, 2017.
} 
tela, a competição partidária nesse estado envolvia um seleto grupo de políticos. Os conflitos surgidos no interior dessa oligarquia foi um fator decisivo para gerar a polarização partidária no estado ao longo da mencionada década.

\section{A vaga do terço e o acesso das oposições estaduais ao Poder Legislativo durante a Primeira República}

A discussão sobre as formas de representação política atravessou as quatro décadas da Primeira República. Os membros de distintas correntes partidárias ocuparam-se, de forma sistemática, de aventar propostas acerca desse tema. Nesse quadro, os estudos históricos têm atentado para a natureza e implicações desse repertório de ideias. Eles têm dedicado ênfase, por exemplo, aos critérios formulados pela elite política nacional para determinar a inclusão e o distanciamento de determinados setores da população da vida eleitoral. ${ }^{7}$

Porém, permanece pouco desenvolvido o estudo sobre as condições de acesso das oposições estaduais às esferas do Poder Legislativo. Há pouca ênfase na análise das formas de representação parlamentar dos oposicionistas. No início dos anos 1890, no contexto das atividades da Assembleia Nacional Constituinte, houve a discussão sobre a garantia do acesso das oposições àquele Poder. No Paraná, o debate sobre as formas de assegurar à oposição o acesso permanente às instituições parlamentares também fez parte da agenda de debates realizados pelos deputados estaduais no início daquela década. Cumpre salientar, portanto, que as decisões tomadas em âmbito nacional e estadual acerca desse tema, nos primeiros anos da República, influenciaram de maneira decisiva o funcionamento da vida política desse estado no decorrer dos anos 1910.

O Artigo 28 da Constituição brasileira de 1891 contém a seguinte determinação: "A Camara dos Deputados compõe-se de representantes do povo eleitos pelos Estados e pelo Districto Federal, mediante o suffragio directo, garantida a representação da minoria". ${ }^{8}$ Esse dispositivo constitucional não foi sucedido por uma lei complementar direcionada a tornar obrigatório o acesso permanente das minorias ao Poder Legislativo. ${ }^{9}$

Houve épocas em que os governistas do Paraná reconheceram que era um dever da situação facultar uma presença mínima das oposições nas instituições legislativas. Em meados dos anos 1890, por exemplo, eles acordaram que à oposição estadual deveria ser destinado um terço das vagas em disputa para os cargos de deputado federal e deputado estadual. Essa destinação ocorria por meio do não preenchimento, pelos situacionistas, de uma chapa

\footnotetext{
7 HOLLANDA, Cristina Buarque de. Modos de representação política na Primeira República. Belo Horizonte: Ed. da UFMG, 2009.

${ }^{8}$ BRASIL. Constituição da República dos Estados Unidos do Brasil (1891). [S.n.t.].

9 Acerca dos efeitos da legislação eleitoral da Primeira República sobre as condições de êxito dos candidatos oposicionistas, ver: FIGUEIREDO, Vítor Fonseca. Voto e competição... Op. cit.
} 
completa de candidatos. As vagas restantes, portanto, seriam ocupadas pelos candidatos mais votados do grupo adversário.

Todavia, a ausência de uma regulamentação precisa sobre o tema criou uma situação na qual a elite política paranaense tinha um entendimento volúvel sobre o assunto. A esse respeito, cabe salientar que, em fins de 1896, o Partido Republicano do Paraná, de orientação governista, decidiu apresentar apenas três candidatos a deputado federal. A quarta vaga seria destinada à oposição. Os dirigentes da agremiação justificaram tal decisão do seguinte modo:

Obedecendo a disposições da lei vigente, apresenta o Partido apenas os candidatos para os dois terços da representação na Câmara dos Deputados, mas se reserva o direito de pleitear o terço destinado à minoria se assim aconselharem as conveniências partidárias, e o fato de não disputar essa representação o partido adversário, que, como é de notoriedade, carece de organização para apresentar-se nas urnas. ${ }^{10}$

As informações contidas nesse excerto permitem a elaboração de duas constatações. Primeiro, nota-se que, nos anos 1890, a agremiação situacionista do Paraná reconhecia formalmente a sua concordância com o preceito constitucional referente à participação permanente da oposição em instituições do Poder Legislativo. A segunda constatação é que essa concordância não significava que os governistas estavam comprometidos, em todas as eleições, a inibir os seus interesses políticos para possibilitar aos seus adversários a conquista de mandatos eletivos. Assim, a passagem acima transcrita contém a insinuação de que a agremiação governista poderia modificar a decisão que acabara de tomar. Em tal contexto, não havia uma imposição legal em favor da abertura da vaga do terço. Desse modo, os governistas poderiam apresentar candidatos às vagas que eventualmente eram destinadas à oposição.

De fato, às vésperas do pleito, realizado no dia 30 de dezembro de 1896, o Partido Republicano do Paraná reformou a decisão tomada no início desse mês. Tal reforma consistiu no lançamento de uma chapa completa de quatro candidatos a deputado federal. Esse lançamento tornou inviável a vitória do candidato de oposição, o engenheiro civil Francisco de Almeida Torres (1848-1902). ${ }^{11}$ Nessa época, a oposição paranaense possuía um grau de organização interna e uma base eleitoral suficiente para lançar uma candidatura. ${ }^{12}$ Ela não reunia as condições para formar uma chapa completa de candidatos dotados da capacidade de superar a votação dos postulantes do partido situacionista. No contexto dos anos 1910, o não

\footnotetext{
${ }^{10}$ A República, Curitiba, 11 dez. 1896, p. 1. Os jornais e anais parlamentares utilizados neste artigo estão disponíveis para consulta no sítio eletrônico da Hemeroteca Digital Brasileira: http://memoria.bn.br.

${ }^{11}$ Nesse pleito, Francisco Torres obteve 2.642 votos, isto é, $11 \%$ do total de sufrágios angariados pelos cinco candidatos. A diferença de votos entre Torres e o terceiro colocado no pleito foi de 1.805 votos. $A$ República, Curitiba, 05 fev. 1897, p. 2.

12 Francisco Torres foi deputado federal pelo Paraná de 1895 a 1896. Elegera-se pelo partido governista. Porém, não conseguiu o apoio dos antigos aliados para tentar a reeleição. A República, Curitiba, 12 jan. 1897, p. 1. Tal informação diz respeito a uma situação que ainda vigorava no Paraná dos anos 1910. Essa situação era aquela em que os principais líderes da oposição estadual eram antigos membros da grei governista. Portanto, no Paraná da Primeira República, um destino comum a uma parcela de situacionistas decaídos era liderar a oposição por um determinado período.
} 
lançamento de uma chapa completa de candidatos a continuou a ser uma característica da oposição paranaense. Durante a Primeira República, houve somente três oportunidades em que os situacionistas do Paraná concederam à oposição a vaga do terço no pleito para deputado federal. Foi nos anos de 1906, 1912 e 1915 que a oposição estadual teve condições de eleger seus postulantes àquele cargo. ${ }^{13}$ Dessa forma, o presente artigo se atém a um período em que os governistas paranaenses cessaram a concessão da vaga do terço e retomaram o controle integral sobre as vagas da bancada do estado na Câmara dos Deputados.

No período em tela, os políticos do Paraná se ocuparam de discutir a questão da representação da oposição nas instâncias parlamentares. Tal assunto foi debatido no Congresso Constituinte do estado, em 1892. Nesse ano, houve a promulgação da Constituição Estadual. Em seu Artigo 114, tal documento comporta a seguinte determinação: "Lei especial regulará o modo de qualificação, o processo e as incompatibilidades eleitorais, garantindo a representação das minorias no Congresso [Estadual] e nas câmaras municipais". ${ }^{14}$ Essa lei complementar jamais foi elaborada. Portanto, manteve-se um entendimento inconstante dos governistas do estado acerca da pertinência de ceder à oposição uma parcela das vagas nas disputas para a Câmara dos Deputados e o Congresso Legislativo Estadual.

Por outra parte, cabe destacar que nos anos 1900 ocorreu uma mudança nas regras eleitorais do Brasil. Assim, a Lei Rosa e Silva (Lei Federal no 1.269, de 15 de novembro de 1904) tinha entre os seus objetivos viabilizar o acesso das minorias à Câmara dos Deputados. ${ }^{15}$ Tal lei determinava que o eleitor votasse em um número de candidatos um algarismo inferior ao total de deputados federais que o seu distrito enviava à Câmara. ${ }^{16}$ No Paraná, contudo, a Lei Rosa e Silva não evitou o controle integral das quatro vagas de deputado federal pela agremiação situacionista, à época denominada de Partido Republicano

\footnotetext{
${ }^{13}$ A República, Curitiba, 19 mar. 1915, p. 1.

14 PARANÁ. Constituição Política do Estado do Paraná (1892). Curitiba: Tipografia da Penitenciária do Ahú, 1909, p. 18.

15 Francisco de Assis da Rosa e Silva (1857-1929), político pernambucano, empenhou-se para a aprovação dessa lei. Portanto, a lei eleitoral de 1904 é identificada pelo nome de tal indivíduo. Contudo, o autor do projeto que originou a mudança na legislação eleitoral brasileira era Anísio Auto de Abreu (1864-1909), deputado federal pelo Piauí no decênio de 1900. PORTO, Walter Costa. A mentirosa urna. São Paulo: Martins Fontes, 2004, p. 77.

${ }^{16} \mathrm{Em}$ verdade, a primeira lei eleitoral do Brasil republicano (Lei Federal n. ${ }^{0} 35$, de 26 de janeiro de 1892) também atentou para o tema da representação das minorias. Tal lei, que vigorou até 1904, buscava tornar essa representação mais ampla e assídua. No Parágrafo quarto de seu Artigo 35, ela determinava que o eleitor votasse em dois terços do número total de representantes do seu distrito eleitoral na Câmara dos Deputados. Essa regra objetivava permitir que o terço restante fosse ocupado por membros da minoria. Em Minas Gerais, por exemplo, tal lei não ocasionou relevante acesso da oposição à Câmara. FIGUEIREDO, Vítor Fonseca. Voto e competição... Op. cit., p. 38. No Paraná, essa lei também não favoreceu a eleição de membros da minoria para deputado federal.
} 
Paranaense (PRP). ${ }^{17}$ Os situacionistas do Paraná não se mostraram indiferentes à aprovação da lei eleitoral de 1904. Inicialmente, eles salientaram que iriam cumpri-la para garantir a presença permanente dos seus adversários nas esferas do Poder Legislativo. Em 1905, no contexto de uma eleição para as trinta vagas do Congresso Legislativo Estadual, o Jornal do Brasil publicou a seguinte notícia:

A reforma eleitoral do Sr. Rosa e Silva acabou de ser executada, pela primeira vez, no Paraná, cujo governo a adotou para as eleições estaduais. A Câmara dos Deputados desse Estado acaba de ficar organizada na seguinte proporção: 20 governistas e 10 oposicionistas. Prova isto que o partido, de que é chefe o Sr. Vicente Machado, respeitou rigorosamente o terço, dando lugar a que o partido da oposição ficasse com uma forte bancada no Congresso. ${ }^{18}$

As informações contidas nessa notícia permitem a elaboração de duas afirmações. Primeiro, constata-se a participação do então governador do Estado, Vicente Machado (18601907), nas articulações para a formação da chapa de candidatos governistas. Verifica-se, em última instância, que ele também desempenhava a função de dirigente partidário. No Brasil, desde os anos 1890, não era raro que os governadores se envolvessem na questão da concessão das vagas do terço. Diante da ausência de critérios precisos acerca de tal concessão, os governadores possuíam a prerrogativa de estipular, junto ao núcleo dirigente dos partidos situacionistas, o contingente de oposicionistas que integrariam as esferas do Poder Legislativo. ${ }^{19}$

A segunda constatação diz respeito ao fato de que o ano de 1905 foi o marco inicial de um período em que os governistas do Paraná facultaram à oposição, de modo mais frequente, uma presença mínima no Congresso Estadual e na Câmara dos Deputados. No fim dos anos 1910, os situacionistas retomaram a prática de apresentar chapas completas a eleições parlamentares. $^{20}$ As mudanças na legislação eleitoral ocorridas no Brasil, em 1904, não tornaram obrigatória a concessão das vagas do terço. Elas apenas estimularam, por meio de regras de votação, a conquista de uma parcela mínima das vagas em disputa pela oposição.

Portanto, os líderes do situacionismo paranaense, nos anos 1910, tiveram a autonomia para sustentar um entendimento diferente em relação àquele que vigorou entre os dirigentes do

\footnotetext{
17 Quando ocorreu a eleição parlamentar de 1918, estava em vigor uma nova lei eleitoral no Brasil (Lei Federal n.o 3.208, de 27 de dezembro de 1916). Essa lei, contudo, não modificou as regras de votação estabelecidas na Lei Rosa e Silva. Para o conhecimento, a partir do caso de Minas Gerais, sobre a relação entre as mudanças na legislação eleitoral e a votação de candidatos oposicionistas a deputado federal na Primeira República, ver: FIGUEIREDO, Vítor Fonseca. Voto e competição... Op. cit.

18 Jornal do Brasil, Rio de Janeiro, 23 dez. 1905, p. 1.

19 Em 1895, por exemplo, o governador de Pernambuco, Alexandre José Barbosa Lima (1862-1931), determinou que o partido governista desse estado cedesse à oposição apenas um sexto das vagas nas eleições de senador e deputado federal. Ele alegou que a Constituição brasileira de 1891 não estipulava um percentual mínimo de participação da oposição nas instâncias do Poder Legislativo. BRASIL. Anais da Câmara dos Deputados. Vol. 2. Rio de Janeiro: Imprensa Nacional, 1895, p. 372.

${ }^{20}$ Em 1917, os governistas do Paraná retomaram a apresentação de chapas completas para o Congresso Legislativo Estadual. Foi interrompida, assim, a destinação aos oposicionistas das dez vagas que correspondiam a um terço do total de cadeiras da instituição. A República, Curitiba, 26 out. 1917, p. 1. Em 1918, eles também voltaram a formar chapas completas de deputados federais. A República, Curitiba, 13 fev. 1918, p. 1.
} 
partido governista ao tempo da sanção da Lei Rosa e Silva. Ou seja, após a eleição parlamentar de 1915 os gestores da agremiação situacionista do Paraná ambicionaram controlar por completo os cargos legislativos em disputa no estado.

\section{As eleições parlamentares no Paraná de 1915: a competição entre antigos apoiadores do situacionismo estadual}

A finalidade desta seção é demonstrar que eram de curta duração as alianças entre os próceres da oposição no Estado do Paraná, no fim dos anos 1910. Um dos principais impactos dessa curta duração consistiu na dificuldade para a formação de uma agremiação partidária internamente organizada e eleitoralmente viável. Os partidos de oposição que surgiram no Paraná, no mencionado recorte temporal, não representaram uma ameaça ao predomínio da agremiação governista. Trata-se de salientar que, em épocas eleitorais, havia a aproximação entre situacionistas que, em virtude da perda de espaço nos diretórios do PRP, migraram para oposição. Todavia, esses indivíduos não assumiram entre si duradouros compromissos partidários. O fato de terem experimentado na mesma época os impactos do afastamento da grei situacionista não foi suficiente para criar entre eles uma consistente aliança política.

Em 1915, houve uma dissidência no interior do PRP. Tal incidente ocorreu durante a escolha dos candidatos a deputado federal e a senador para o pleito que se realizaria no início daquele ano. O grupo de governistas liderado pelo senador Manuel de Alencar Guimarães (1865-1940) não conseguiu preencher a chapa do partido com os candidatos de sua preferência. Em seguida, abriram uma dissidência no partido e criaram a Concentração Republicana. ${ }^{21}$ Essa entidade não tinha por objetivo se tornar um partido político dotado de ampla presença nos municípios do estado. A fundação de tal grupo possuía o propósito de permitir que os dissidentes permanecessem politicamente articulados, pelo período de uma eleição, para lançar as suas candidaturas parlamentares. A Concentração foi, em suma, uma entidade política de oposição que se extinguiu em $1916 .^{22}$

Cabe ressaltar que, nessa época, Alencar Guimarães não pertencia ao PRP. Ele era o dirigente, no Paraná, de uma agremiação nacional denominada Partido Republicano Conservador (PRC), cujo líder maior era o senador José Gomes Pinheiro Machado (1851-1915), do Rio Grande do Sul. Antes da abertura da mencionada dissidência, o PRC estava aliado ao PRP. ${ }^{23}$ Portanto, Alencar Guimarães possuía a legitimidade de formular sugestões sobre o

\footnotetext{
${ }^{21}$ GOULART, Mônica Helena Harrich Silva. Classe dominante e... Op. cit., p. 165.

${ }^{22}$ A República, Curitiba, 14 dez. 1916, p. 1.

${ }^{23}$ A República, Curitiba, 21 jan. 1915, p. 1.
} 
lançamento das candidaturas parlamentares da agremiação predominante no estado. A dificuldade de esse senador influir nas tomadas de decisão do PRP e a existência de governistas que se opunham às orientações do núcleo dirigente dessa grei levaram à criação da Concentração Republicana. Tais episódios não comportam apenas informações sobre a natureza das dissensões internas à elite política do Paraná. Eles também possuem evidências acerca dos limites da ação eleitoral de partidos estaduais de oposição no estado.

Assim, convém salientar que a abertura de uma dissidência no PRP não implicou a transferência de antigos situacionistas para o PRC. Os dissidentes, portanto, não se comprometeram a auxiliar na estruturação local de um partido nacional. De fato, os dissidentes aceitaram que o dirigente estadual do PRC, Alencar Guimarães, fosse investido na condição de líder da oposição estadual. Entretanto, o reconhecimento da autoridade desse parlamentar sobre os oposicionistas não significava o compromisso destes em promover a consolidação do PRC. O incidente que causou a saída de veteranos políticos do PRP não foi sucedido por um processo de interiorização de diretórios e aumento do grau de organização interna do PRC do Paraná.

Tal agremiação conheceu o enfraquecimento de sua força eleitoral no Paraná após a morte de seu presidente nacional, Pinheiro Machado, em setembro de 1915 . Esse acontecimento não gerou o desaparecimento dessa agremiação nos estados. Em verdade, havia diferenças regionais quanto às condições de funcionamento dessa grei. ${ }^{24}$ De sua parte, Alencar Guimarães não conseguiu que o PRC paranaense agregasse, de forma permanente, os oposicionistas do estado. ${ }^{25}$ No caso do Paraná, a abertura de uma dissidência na grei governista não era uma oportunidade para a construção de um partido político dotado de alto grau de formalização de sua vida interna.

Dessa forma, a fundação da Concentração Republicana consiste em uma evidência de que a oposição paranaense, nos anos 1910, possuía duas formas de ação eleitoral. Uma forma era a manutenção de efêmera coligação entre os antagonistas do grupo governista. A criação de tal aliança não ocasionava a implantação de um partido político. Ao contrário, essa unidade entre os próceres da oposição estadual se desfazia após o término de um período eleitoral. A outra forma de ação eleitoral era o lançamento de candidaturas avulsas. Esse lançamento era um indício da dificuldade de os líderes da oposição paranaense unir os adversários do partido predominante no estado.

Diante de tais dificuldades da oposição, a participação da Concentração Republicana na eleição parlamentar de 1915 guarda semelhanças com a forma de ação política das oposições nos estados brasileiros em tal contexto. Uma dessas semelhanças era a formação de uma

\footnotetext{
${ }^{24}$ Existiam estados em que o PRC detinha maior força eleitoral. Em 1918, por exemplo, o governador do Ceará pertencia a esse partido. Jornal do Brasil, Rio de Janeiro, 25 jun. 1918, p. 4. Em 1919, o PRC de Sergipe conseguiu eleger um senador. Jornal Brasil, Rio de Janeiro, 12 jan. 1919, p. 6. Nessa época, contudo, tal agremiação não mais funcionava no Paraná. Dessa forma, a efêmera duração de partidos que abrigavam oposicionistas foi um elemento intrínseco à vida política paranaense na mencionada década.
}

${ }^{25}$ O Estado de S. Paulo, São Paulo, 22 set. 1915, p. 1. 
chapa incompleta de candidatos a deputado federal. Habitualmente, as oposições não ambicionavam suplantar por completo as chapas de candidatos governistas. Elas costumavam lançar candidatos únicos para impedir que a existência de diversas candidaturas de oposição gerasse a dispersão dos votos do seu incipiente eleitorado. A estratégia mais recorrente das oposições, portanto, era concentrar os sufrágios em apenas um indivíduo com a finalidade de assegurar uma presença mínima na Câmara dos Deputados. ${ }^{26}$

Em 1915, a Concentração Republicana apresentou um candidato a senador e dois candidatos a deputado federal. Essa grei, portanto, optou por não pleitear as quatro vagas abertas à Câmara. A decisão de lançar uma chapa incompleta foi enxergada pelos governistas do Paraná como um indício da reduzida força política da nova agremiação. Dedicar atenção às seguintes observações do redator de $A$ República, periódico situacionista, permite salientar os principais entraves da ação eleitoral da oposição paranaense em tal época:

A chapa da oposição contém dois nomes para deputado e o do candidato à senatoria. Reconhece, assim, o senador Alencar que apenas poderá eleger um ou dois deputados, usando para isso do recurso da acumulação de votos nos seus candidatos. Quanto aos deputados, o Partido Republicano Paranaense poderia eleger sem dificuldades se, em obediência ao preceito constitucional, não tivesse resolvido respeitar o terço, deixando um lugar para ser disputado pela oposição. ${ }^{27}$

As considerações elaboradas pelo articulista permitem a sustentação de três constatações. Primeiro, cabe salientar que os oposicionistas do Paraná tinham como objetivo central assegurar apenas uma presença mínima na Câmara dos Deputados. Eles reconheciam, desde o princípio da campanha, que estavam vinculados a uma estrutura partidária que não Ihes permitia competir em condições de igualdade com o partido situacionista. Analisados na presente seção, os dados da Tabela 2 possibilitam ressaltar que em estados formados por apenas um distrito eleitoral, nos anos 1910, não era frequente o confronto entre duas chapas completas de candidatos.

A segunda constatação é de que o redator reconheceu que a abertura de uma vaga do terço significava uma concessão dos governistas à oposição. Ou seja, nesse contexto a presença da oposição no Congresso Nacional era enxergada como dependente das decisões dos governistas acerca de suas estratégias e interesses eleitorais.

A terceira constatação diz respeito ao fato de que redator observou que a vaga do terço era disputada entre os integrantes da oposição. Ele salientou que, em virtude das dificuldades para se consolidar como um grupo político eleitoralmente viável, a oposição estadual não tinha condições de suplantar os candidatos da situação nas eleições parlamentares. Desse modo, os oposicionistas competiam entre si pelas vagas ocasionalmente cedidas pelo partido predominante. De outra parte, o estudo sobre o perfil político e o desempenho eleitoral dos candidatos a deputado federal pelo Paraná em 1915 requer a atenção às informações contidas na Tabela 1.

${ }^{26}$ FIGUEIREDO, Vítor Fonseca. Voto e competição... Op. cit., p. 47.

${ }^{27}$ A República, Curitiba, 27 jan. 1915, p. 1. 
Tabela 1 - Votação de candidatos eleitos e não eleitos a deputado federal pelo Estado do Paraná (1915)

\begin{tabular}{|l|c|c|c|c|c|c|}
\hline \multicolumn{1}{|c|}{ Nome } & Profissão & Partido & Posição & Votação & $\begin{array}{c}\text { Votação } \\
\text { (\%) }\end{array}$ & Resultado \\
\hline Luiz Antônio Xavier & Tabelião & PRP & Situação & 14.539 & 25,6 & Eleito \\
\hline João David Perneta & $\begin{array}{c}\text { Engenheiro } \\
\text { civil }\end{array}$ & PRP & Situação & 14.498 & 25,5 & Eleito \\
\hline $\begin{array}{l}\text { Luiz Bartolomeu de } \\
\text { Souza e Silva }\end{array}$ & Jornalista & PRP & Situação & 14.417 & 25,4 & Eleito \\
\hline $\begin{array}{l}\text { Alberto Ferreira de } \\
\text { Abreu }\end{array}$ & Militar & $\begin{array}{c}\text { Concentração } \\
\text { Republicana }\end{array}$ & Oposição & 6.814 & 12,1 & Eleito \\
\hline $\begin{array}{l}\text { Antônio Augusto de } \\
\text { Carvalho Chaves }\end{array}$ & Advogado & $\begin{array}{c}\text { Concentração } \\
\text { Republicana }\end{array}$ & Oposição & 6.456 & 11,4 & Não eleito \\
\hline
\end{tabular}

Fonte: BRASIL. Anais da Câmara dos Deputados. Vol. 2. Rio de Janeiro: Imprensa Nacional, 1916, p. 786.

Os dois candidatos a deputado federal pela Concentração Republicana eram antigos apoiadores da agremiação governista do Paraná. O general Alberto Ferreira de Abreu (18531933) aderiu à oposição na época em que Alencar Guimarães, de quem era primo pelo lado materno, rompeu com o situacionismo. O bacharel Antônio Augusto de Carvalho Chaves (1875-1949), por sua vez, fora deputado federal pelo PRP antes de migrar para a oposição. Por fim, o candidato a senador da Concentração, o advogado Francisco Xavier da Silva (18381922), também pertencera aos quadros do partido situacionista. ${ }^{28}$

A fundação da Concentração Republicana não propiciou o surgimento de novas lideranças no campo da oposição estadual. No período em tela, no Paraná, eram os políticos veteranos que controlavam as vagas em disputa nas eleições parlamentares. Em resumo, a Concentração foi um projeto encampado, durante uma campanha eleitoral, por indivíduos que não conseguiram ter os seus nomes incluídos em chapas de candidatos da agremiação predominante no estado.

A análise da Tabela 1 permite salientar que a votação dos postulantes da Concentração não representou uma ameaça à eleição dos governistas. A existência de uma vaga do terço, portanto, foi crucial para que a oposição tivesse um representante na Câmara dos Deputados. Nesse pleito, os adversários do PRP conseguiram amealhar pouco menos de um quarto do total de votos destinados aos cinco postulantes. Na eleição para o Senado, a oposição também conquistou cerca de um quarto dos votos. O candidato governista, Ubaldino do Amaral Fontoura (1842-1920), obteve 14.506 sufrágios (76,5\%). De sua parte, o oposicionista Xavier da Silva angariou 4.479 votos $(23,5 \%){ }^{29}$

\footnotetext{
${ }^{28}$ Para o conhecimento do perfil social dos congressistas paranaenses durante a Primeira República, ver: ABREU, Alzira Alves de (coord.). Dicionário histórico-biográfico da Primeira República (1889-1930). Rio de Janeiro: Ed. FGV, 2015.
}

${ }^{29}$ A República, Curitiba, 06 fev. 1915, p. 2. 
A eleição de um deputado federal e de um senador pela Concentração Republicana permite salientar que, no Paraná, a baixa competitividade eleitoral da oposição exigia a utilização de determinados artifícios para que os seus candidatos pudessem se tornar mandatários. O artifício que viabilizou a eleição do general Alberto de Abreu consistiu na abertura de uma vaga do terço. Assim, era necessário o consentimento dos governistas do Paraná para haver a temporária presença de um membro da oposição estadual em esfera do Poder Legislativo.

Por outro lado, cabe salientar que, a despeito de ter sido derrotado por Ubaldino do Amaral, Xavier da Silva foi empossado como senador. Essa posse foi decorrente do fato de que a Comissão de Verificação de Poderes do Senado não validou a eleição de Amaral. A Comissão alegou a que houve irregularidades na apuração dos votos. Amaral, portanto, foi barrado pela degola. Tal prática era empregada pelas Comissões de Poderes da Câmara e do Senado para evitar que os opositores dos partidos governistas tivessem acesso ao Congresso Nacional. ${ }^{30}$ Contudo, Alencar Guimarães, que era membro da Comissão de Poderes da Câmara Alta, articulou para que a degola de Amaral fosse realizada em favor de Xavier da Silva. ${ }^{31}$

Dessa forma, a concessão de vaga do terço e a degola do candidato a senador mais votado foram artifícios que possibilitaram aos oposicionistas do Paraná conseguir, durante a Primeira República, as últimas oportunidades de eleger seus candidatos ao Congresso Nacional. A partir de 1918, o fim da concessão da vaga do terço para deputado federal implicou, para a oposição paranaense, a redução de sua base eleitoral e o término de sua atuação em uma instituição política nacional.

Cumpre, por conseguinte, identificar as aproximações entre a vida eleitoral Paraná dos anos 1910 e a vida eleitoral dos estados que em tal época também eram compostos por distrito eleitoral único. Para tanto, atente-se às informações da Tabela 2.

\footnotetext{
30 LESSA, Renato. A invenção republicana: Campos Sales, as bases e a decadência da Primeira República. Rio de Janeiro: Vértice, 1988, p. 106.

${ }^{31}$ Gazeta de Notícias, Rio de Janeiro, 08 jun. 1915, p. 2. Para o conhecimento do parecer que invalidou a eleição de Ubaldino do Amaral, ver: BRASIL. Anais do Senado Federal. Sessões de 1 a 30 de junho de 1915. Vol. 3. Rio de Janeiro: Imprensa Nacional, 1918, p. 69-105.
} 
Tabela 2 - Votação de candidatos eleitos e não eleitos a deputado federal em 1915 (estados de distrito eleitoral único) $)^{32}$

\begin{tabular}{|c|c|c|c|c|c|c|}
\hline Estado & $\begin{array}{c}\text { Candidatos } \\
\text { eleitos }\end{array}$ & $\begin{array}{c}\text { Total de } \\
\text { votos dos } \\
\text { candidatos } \\
\text { eleitos }\end{array}$ & $\begin{array}{c}\text { Votação dos } \\
\text { candidatos } \\
\text { eleitos (\%) }\end{array}$ & $\begin{array}{c}\text { Candidatos } \\
\text { não eleitos }\end{array}$ & $\begin{array}{c}\text { Total de } \\
\text { votos dos } \\
\text { candidatos } \\
\text { não eleitos }\end{array}$ & $\begin{array}{c}\text { Votação dos } \\
\text { candidatos } \\
\text { não eleitos } \\
\text { (\%) }\end{array}$ \\
\hline ES & 4 & 13.287 & 64,6 & 7 & 7.274 & 33,4 \\
\hline MA & 7 & 80.027 & 82,3 & 11 & 17.419 & 17,7 \\
\hline MT & 4 & 8.733 & 74,7 & 2 & 2.955 & 25,3 \\
\hline PA & 7 & 168.304 & 86,8 & 3 & 25.587 & 13,2 \\
\hline PR & 4 & 50.268 & 88,9 & 1 & 6.456 & 11,1 \\
\hline RN & 4 & 29.362 & 92,3 & 3 & 2.422 & 7,7 \\
\hline SC & 4 & 32.065 & 84,1 & 1 & 6.062 & 15,9 \\
\hline
\end{tabular}

Fonte: BRASIL. Anais da Câmara dos Deputados. Vols. 2-6. Rio de Janeiro: Imprensa Nacional, 1916.

As informações expostas nesta Tabela permitem a elaboração de duas afirmações. Primeiro, cabe salientar que, na referida época, não era comum que houvesse o enfrentamento de duas chapas completas de candidatos. Por consequência, há indícios de que, nos referidos estados de distrito eleitoral único, não existiam ao menos dois partidos dotados da organização interna e base eleitoral necessária para almejar a conquista de todas as vagas em disputa para a Câmara dos Deputados.

Foi apenas no Espírito Santo e no Maranhão que houve, em 1915, um número maior de candidatos não eleitos do que de candidatos eleitos a deputado federal. Tal situação, contudo, não autoriza afirmar que ambos os estados eram marcados pela existência de consistentes partidos de oposição. No Espirito Santo, dos sete candidatos não eleitos, quatro tiveram votações inferiores a mil sufrágios. O postulante menos votado nessa ocasião teve apenas 46 votos. $^{33}$ No Maranhão, dos onze candidatos não eleitos, seis tiveram votações inferiores 500 sufrágios. Nesse particular, cabe destacar que os três últimos colocados no pleito obtiveram apenas um voto. ${ }^{34}$ Dessa forma, o aumento do número de candidatos não era decorrente, em todos os casos, do fortalecimento da oposição. Em uma época em que não existia o controle de órgãos do Estado sobre a homologação de candidaturas, havia situações nas quais indivíduos que não se apresentaram como candidatos tinham os seus nomes sufragados. ${ }^{35}$

\footnotetext{
32 Nesse contexto, vigorava o distrito eleitoral único nos estados que possuíam uma bancada na Câmara Federal composta por até sete deputados. Tal regra está contida no Artigo 58 da Lei Federal número 1.269 , de 15 de novembro de 1904.

${ }^{33}$ BRASIL. Anais da Câmara dos Deputados. Vol. 6. Rio de Janeiro: Imprensa Nacional, 1916, p. 311.

${ }^{34}$ Ibidem, vol. 2, p. 41.

${ }^{35}$ A respeito das regras de votação e do lançamento de candidaturas na época anterior à criação da Justiça Eleitoral no Brasil, ver: PORTO, Walter Costa. O voto no Brasil: da Colônia à 6a República. Rio de Janeiro: Topbooks, 2002.
} 
A segunda constatação afirma que o lançamento de diversas candidaturas não significava uma competição mais equilibrada entre os candidatos. Na maior parte dos estados de distrito eleitoral único que tiveram eleições no início de 1915, o conjunto de candidatos derrotados não conseguiu angariar o apoio de parcela superior a um quinto do eleitorado. $O$ lançamento de distintas candidaturas a deputado federal nos estados de distrito único é uma evidência da limitada influência política dos partidos de oposição, pois não conseguiam unir os oposicionistas em torno de um candidato de consenso. As candidaturas independentes geravam a divisão dos votos eleitorado da oposição. Essa divisão ocorreu no Paraná, na eleição de 1918.

\section{Supressão da vaga do terço, divergências internas à oposição e lançamento de candidatura avulsa: as eleições parlamentares no Paraná de 1918}

Há dois argumentos sustentados nesta seção. Primeiro, cumpre evidenciar que, na eleição para a Câmara dos Deputados ocorrida no Paraná, em 1918, a oposição estava cindida. Um indício dessa cisão foi o lançamento de uma candidatura avulsa. Os líderes da oposição estadual não conseguiram amplas adesões para o candidato de sua preferência. Dessa forma, um argumento sustentado no decorrer desta abordagem afirma que as dissensões internas à oposição paranaense tinham impactos no desempenho eleitoral dos antagonistas do situacionismo. Um desses impactos era a dispersão de votos entre candidatos eleitoralmente pouco competitivos. Outro impacto era a dificuldade para manter em funcionamento um partido político por longo período.

O segundo argumento salienta que, no referido ano, a oposição paranaense permaneceu sob o domínio de antigos membros da ordem situacionista. Em tal contexto, não houve a renovação do grupo de líderes oposicionistas. Nesse particular, cumpre salientar que uma aproximação entre a agremiação governista e o partido de oposição então existente no Paraná era o fato de que eram inclinados a não renovar o rol de candidatos a deputado federal. As chapas de postulantes à Câmara dos Deputados eram preenchidas por indivíduos politicamente ativos desde o início da Primeira República. Nesse contexto, o lançamento de candidaturas avulsas era uma prática adotada por veteranos que perderam espaço tanto no partido governista quanto na agremiação oposicionista. As informações analisadas nesta seção permitem destacar que a elite política paranaense possuía nessa época o aspecto de uma oligarquia competitiva. Ou seja, os embates partidários no estado envolviam um pequeno conjunto de indivíduos. Desde os anos 1890, tais indivíduos controlavam as posições centrais no jogo político do Paraná. 
Em 1918, o senador Alencar Guimarães continuava a liderar a oposição paranaense. Nessa ocasião, ele buscou retomar as atividades do PRC. Foi por este partido que, no mencionado ano, ocorreu o lançamento de uma candidatura oposicionista a deputado federal pelo Paraná. Tal informação permite corroborar a afirmação que a morte de Pinheiro Machado não implicou, em todos os estados brasileiros, o desparecimento dos diretórios regionais da grei. Após o falecimento desse político, o PRC assumiu o aspecto de um conjunto de diretórios estaduais pouco ligados entre si. ${ }^{36}$ Nesse quadro, o Paraná foi um estado no qual esse partido continuou a funcionar de modo circunstancial. Mais precisamente, ele funcionou até o fim dos anos 1910 para sustentar as pretensões eleitorais de membros da oposição.

Um dos fatores da breve existência do PRC paranaense era o fato de que a agremiação não conseguiu possuía uma vida interna estável. A Convenção partidária realizada em janeiro de 1918 evidenciou que em tal partido não havia unidade entre os correligionários. Naquele ano, por exemplo, a candidatura a deputado federal de Randolfo Pereira de Serzedelo (18621919), ex-deputado estadual pela situação, não contou com unânime aprovação dos membros da grei. ${ }^{37}$

Cumpre ressaltar que a opção pelo lançamento de apenas uma candidatura é uma evidencia de que o PRC paranaense adotava a estratégia eleitoral mais frequente entre as oposições estaduais. Desprovidos da estrutura partidária necessária para formar uma chapa de candidatos eleitoralmente competitivos, a agremiação decidiu assegurar apenas uma vaga na Câmara dos Deputados. Em um cenário marcado por limitada base eleitoral do PRC, o lançamento de uma chapa completa por tal agremiação poderia ocasionar a dispersão dos votos do seu eleitorado. A princípio, a agremiação cogitou apresentar duas candidaturas a deputado federal. A Convenção do partido, ao final, decidiu pela homologação de apenas um nome. ${ }^{38}$ De todo modo, nota-se que a formação de uma chapa completa contendo quatro postulantes não fazia parte das estratégias eleitorais dessa grei.

Na Convenção do PRC, uma das justificativas apresentadas para a não apresentação de duas candidaturas era de que, se ela se concretizasse, os governistas não abririam a vaga do terço a deputado federal. ${ }^{39}$ Essa informação é um indício de que, no Paraná do fim dos anos 1910, um dos critérios para os governistas abrirem tal vaga era o baixo grau de competitividade da oposição. O lançamento de candidaturas que ameaçassem o predomínio eleitoral da situação tornava inviável a concessão daquela vaga.

Em 1919, o PRC estava extinto no Paraná. Nesse ano, Alencar Guimarães era o dirigente do Partido Autonomista, o qual não teve longa duração. Tal agremiação não conseguiu unir as lideranças oposicionistas. ${ }^{40}$ Essa grei foi dissolvida em 1921, após malograr

\footnotetext{
36 Jornal do Brasil, Rio de Janeiro, 09 dez. 1918, p. 4.

${ }^{37}$ Diário da Tarde, Curitiba, 01 fev. 1918, p. 1.

${ }^{38}$ Idem.

${ }^{39}$ Idem.

${ }^{40}$ A República, Curitiba, 22 out. 1919, p. 1.
} 
nas eleições municipais ocorridas no ano anterior. ${ }^{41} \mathrm{Em}$ suma, os partidos comandados desde o ano de 1915 por Alencar Guimarães não tiveram êxito na tarefa promover o crescimento do eleitorado oposicionista no Paraná.

Em virtude da falta de amplo eleitorado, uma dificuldade enfrentada pela oposição paranaense no pleito de 1918 era a ausência da vaga do terço. Inicialmente, o partido governista do estado planejara lançar somente três candidatos a deputado federal. Haveria, portanto, a cessão de uma vaga à oposição. Entretanto, quinze dias antes do pleito houve a homologação de uma candidatura que serviu para completar uma chapa de quatro postulantes governistas à Câmara dos Deputados. ${ }^{42}$

Nesse contexto, o preceito constitucional referente à garantia mínima de representação parlamentar da minoria não era acatado de forma irrestrita pelo PRP. Por consequência, o lançamento de uma chapa completa de candidatos governistas dizimou as chances de a oposição experimentar o aumento de sua força eleitoral no estado. De fato, a análise das informações da Tabela 3 permite evidenciar que, em comparação com os resultados da eleição de 1915, a votação obtida pelos oposicionistas em 1918 foi pouco expressiva. Há que se destacar, portanto, que no mencionado contexto a ausência de uma vaga do terço ocasionou a redução do número de apoiadores dos candidatos da oposição paranaense. Para o reconhecimento de aspectos do perfil político e do desempenho eleitoral dos candidatos a deputado federal pelo Paraná no citado ano, atente-se às informações da seguinte Tabela:

Tabela 3 - Votação de candidatos eleitos e não eleitos a deputado federal pelo Estado do Paraná (1918)

\begin{tabular}{|l|c|c|c|c|c|c|}
\hline \multicolumn{1}{|c|}{ Nome } & Profissão & Partido & Posição & Votação & $\begin{array}{c}\text { Votação do } \\
\text { candidato (\%) }\end{array}$ & Resultado \\
\hline $\begin{array}{l}\text { Ottoni Ferreira } \\
\text { Maciel }\end{array}$ & Jornalista & PRP & Situação & 6.175 & 21,8 & Eleito \\
\hline Luiz Antônio Xavier & Tabelião & PRP & Situação & 6.100 & 21,6 & Eleito \\
\hline $\begin{array}{l}\text { Luiz Bartolomeu de } \\
\text { Souza e Silva }\end{array}$ & Jornalista & PRP & Situação & 6.091 & 21,5 & Eleito \\
\hline João David Perneta & $\begin{array}{c}\text { Engenheiro } \\
\text { civil }\end{array}$ & PRP & Situação & 6.015 & 21,4 & Eleito \\
\hline $\begin{array}{l}\text { Randolfo Pereira de } \\
\text { Serzedelo }\end{array}$ & Médico & PRC & Oposição & 3.575 & 12,7 & Não eleito \\
\hline Leôncio Correia & Jornalista & $\begin{array}{c}\text { Sem } \\
\text { partido }\end{array}$ & Oposição & 293 & 1 & Não eleito \\
\hline
\end{tabular}

Fonte: BRASIL. Anais da Câmara dos Deputados. Vol. 1. Rio de Janeiro: Imprensa Nacional, 1919, p. 8586.

Dentre os indivíduos mencionados nesta Tabela, apenas Ottoni Ferreira Maciel (18701944) era um novato na disputa por uma vaga na Câmara dos Deputados. A prática da

\footnotetext{
${ }^{41}$ A República, Curitiba, 23 jun. 1920, p. 1.

${ }^{42}$ A República, Curitiba, 13 fev. 1918, p. 1.
} 
reeleição era, portanto, avalizada pelo núcleo dirigente do PRP. Nesse contexto, cabe mencionar que Luiz Antônio Xavier (1856-1933) era incluído na chapa governista de candidatos a deputado federal desde o ano de $1912 .^{43}$

Ao mesmo tempo, cumpre ressaltar que a obtenção de sucessivas reeleições pela agremiação governista não era um indício de um consistente pertencimento do mandatário à cúpula do partido. O citado Antônio Chaves, por exemplo, foi deputado federal pelo PRP em quatro legislaturas. Ao perder a capacidade de influir nas decisões do núcleo dirigente da grei, vinculou-se à oposição em 1915. De sua parte, João Perneta (1874-1933) foi confirmado pelo partido governista como candidato à reeleição para a Câmara dos Deputados, em 1918, duas semanas antes do pleito. A decisão inicial do partido, contudo, era exclui-lo da disputa em benefício da abertura de uma vaga do terço à oposição. ${ }^{44} \mathrm{O}$ exercício de um mandato de deputado federal pelo PRP não era, em suma, uma evidência de que o político possuía irrestrito apoio dos dirigentes da grei.

Por outro lado, os governistas que passavam para a oposição não modificavam o seu entendimento sobre a finalidade e o modo de gestão de um partido político. Dessa forma, uma função primordial dos partidos de oposição do Paraná era promover as candidaturas parlamentares de um seleto conjunto de políticos veteranos. Essas agremiações aproximavam, durante uma campanha eleitoral, antigos situacionistas que enxergavam na filiação partidária uma forma de obterem um desempenho eleitoral mais expressivo do que aquele conquistado por uma candidatura independente.

Na Tabela 3, constam os nomes de Leôncio Correia (1865-1950) e Randolfo Pereira de Serzedelo como candidatos de oposição. Esses antigos governistas exerciam, desde os anos 1900, a condição de próceres da oposição paranaense. Eles atuaram juntos, em 1909, no projeto malogrado de implantar uma agremiação oposicionista no Paraná, o Partido Republicano Federal (PRF). ${ }^{45}$ Eles também eram veteranos nas disputas para a Câmara dos Deputados. Correia foi deputado federal pelo Paraná de 1897 a 1899, quando ainda integrava o grupo governista. Em 1909, Serzedelo não teve êxito ao pleitear esse cargo. ${ }^{46}$

Por fim, cabe salientar que um dos indivíduos que pleiteara, sem sucesso, ser indicado candidato a deputado federal pelo PRC paranaense em 1918 era o médico João de Menezes Dória (1857-1934). Ele se lançou na disputa para esse cargo nos pleitos de 1906, 1909 e 1912. Porém, obteve sucesso apenas em sua primeira candidatura. ${ }^{47}$ No período em tela, não se verificou a ascensão de lideranças partidárias no campo da oposição estadual. As posições centrais nos diretórios partidários e nas chapas de candidatos da oposição e da situação eram

\footnotetext{
${ }^{43}$ A República, Curitiba, 19 jan. 1909, p. 1.

${ }^{44}$ A República, Curitiba, 13 fev. 1918, p. 1.

45 A República, Curitiba, 13 jan. 1909, p. 2.

${ }^{46}$ A República, Curitiba, 02 mar. 1909, p. 1.

${ }^{47}$ BRASIL. Anais da Câmara dos Deputados. Vol. 1. Rio de Janeiro: Imprensa Nacional, 1906, p. 115.
} 
controladas por indivíduos que, ao menos desde os anos 1900, já possuíam experiência na vida parlamentar.

Em 1918, a oposição paranaense não estava unida em torno de um mesmo candidato para deputado federal. O lançamento da candidatura avulsa de Leôncio Correia para esse cargo é uma evidência das dificuldades de o partido oposicionista, o PRC, exercer o controle sobre a ação eleitoral de indivíduos que há tempos eram contendores do situacionismo estadual. Em verdade, desde o fim dos anos 1900 os efêmeros partidos de oposição fundados no Paraná não conseguiam manter a unidade da oposição ao redor de candidatos de consenso. Portanto, havia membros da oposição estadual que não reconheciam tais agremiações como legitimadas a homologar candidaturas a deputado federal em nome do campo oposicionista.

Nesse quadro, cabe destacar que em 1909 o PRF não evitou o lançamento da candidatura independente de um opositor do governismo. ${ }^{48} \mathrm{Em} \mathrm{1912,} \mathrm{o} \mathrm{Partido} \mathrm{Independente,}$ que também teve curta duração, não impediu a existência de três candidaturas avulsas. ${ }^{49}$ Em 1918, por fim, o PRC não conseguiu absorver Leôncio Correia aos seus quadros. Tal fato é uma evidência de que houve membros históricos da oposição paranaense que optaram por não assumir compromissos partidários. ${ }^{50}$

Cabe, pois, formular três constatações sobre a atuação política da oposição paranaense no fim dos anos 1910. Uma constatação consiste no fato de que os antagonistas do PRP estavam articulados para lançar candidaturas e manter partidos em funcionamento. Ou seja, a oposição estadual não se abstinha de participar das eleições, apesar da incipiente estrutura partidária que sustentava os seus candidatos. Uma parcela dos oposicionistas, em verdade, tinha por objetivo manter partidos em permanente funcionamento. Havia membros da oposição estadual que ambicionaram implantar uma agremiação partidária dotada de um elevado nível de formalização. A manutenção de um diretório do PRC no Paraná foi, pois, uma iniciativa destinada à realização desse objetivo.

A segunda constatação diz respeito ao fato de que eram volúveis as alianças entre os oposicionistas. As pretensões eleitorais divergentes e as disputas por posições de relevo no controle dos partidos de oposição eram fatores que minavam tais alianças. As instáveis relações entre os líderes oposicionistas foram decisivas para impedir a consistente implantação e interiorização de partidos de oposição no estado.

A terceira constatação, por fim, afirma que a ausência de uma coesão interna impediu que a oposição paranaense deflagrasse uma ação em favor da formação de uma estável base eleitoral. Os resultados eleitorais apresentados nas Tabelas 1 e $\mathbf{3}$ permitem asseverar que tal base experimentou significativa diminuição ao tempo em que o PRP não oferecia aos seus contendores a vaga do terço.

\footnotetext{
48 A República, Curitiba, 02 mar. 1909, p. 1.

49 BRASIL. Anais da Câmara dos Deputados. Vol. 1. Rio de Janeiro: Imprensa Nacional, 1912, p. 38.

${ }^{50}$ Diário da Tarde, Curitiba, 17 jan. 1918, p. 1.
} 
A elaboração de um comparativo entre a vida política paranaense e a vida política politica de outros estados formados, em 1918, por somente um distrito eleitoral exige a atenção às informações apresentadas na seguinte Tabela:

Tabela 4 - Votação de candidatos eleitos e não eleitos a deputado federal em 1918 (estados de distrito eleitoral único)

\begin{tabular}{|c|c|c|c|c|c|c|}
\hline Estado & $\begin{array}{c}\text { Candidatos } \\
\text { eleitos }\end{array}$ & $\begin{array}{c}\text { Votos dos } \\
\text { candidatos } \\
\text { eleitos }\end{array}$ & $\begin{array}{c}\text { Votação dos } \\
\text { candidatos } \\
\text { eleitos (\%) }\end{array}$ & $\begin{array}{c}\text { Candidatos } \\
\text { não eleitos }\end{array}$ & $\begin{array}{c}\text { Votos dos } \\
\text { candidatos } \\
\text { não eleitos }\end{array}$ & $\begin{array}{c}\text { Votação dos } \\
\text { candidatos } \\
\text { não eleitos } \\
\text { (\%) }\end{array}$ \\
\hline AM & 4 & 7.605 & 75,1 & 4 & 2.520 & 24,9 \\
\hline ES & 4 & 17.467 & 87,2 & 4 & 2.549 & 12,8 \\
\hline MA & 7 & 49.514 & 91,4 & 4 & 4.660 & 8,6 \\
\hline PA & 7 & 70.231 & 96,1 & 3 & 2.839 & 3,9 \\
\hline PB & 5 & 47.438 & 99 & 1 & 441 & 1 \\
\hline PR & 4 & 24.381 & 86,3 & 2 & 3.868 & 13,7 \\
\hline RN & 4 & 14.963 & 97 & 1 & 455 & 3 \\
\hline SE & 4 & 14.486 & 74 & 5 & 5.089 & 26 \\
\hline
\end{tabular}

Fonte: BRASIL. Anais da Câmara dos Deputados. Vols. 1-2. Rio de Janeiro: Imprensa Nacional, 1919.

Há, pois, duas constatações a serem desenvolvidas. Primeiro, cabe salientar que no referido ano permanecia inalterada uma situação verificada na eleição parlamentar de 1915. Tal situação era que não havia, na maior parte dos estados de distrito eleitoral único, o enfrentamento de ao menos duas chapas de candidatos. Portanto, os candidatos de oposição não possuíam a base eleitoral e a organização partidária adequada para tentar suplantar por completo os postulantes da situação. Nos distritos únicos, um número maior de candidatos não eleitos do que de eleitos não significava, em todas as situações, a existência de uma vida política marcada pela coexistência de diferentes partidos. Em Sergipe, por exemplo, três dos cinco indivíduos não eleitos tiveram votações inferiores a sete sufrágios. ${ }^{51}$ Assim, é factível considerar que eles não se apresentaram como candidatos, apenas tiveram os seus nomes lembrados por um ínfimo número de eleitores. Dessa forma, as regras eleitorais da época permitiram que tais nomes fossem considerados no cômputo final dos votos.

${ }^{51}$ BRASIL. Anais da Câmara dos Deputados. Vol. 1. Rio de Janeiro: Imprensa Nacional, 1919, p. 406. 
A segunda constatação afirma que não era incomum que o lançamento de uma candidatura avulsa fosse um expediente empregado, em diferentes estados, por indivíduos que perdiam espaço em partidos situacionistas. Tal modalidade de candidatura era também uma alternativa a indivíduos que não possuíam sólido pertencimento a coligações ou partidos de oposição. Na Tabela 4, nota-se que, em 1918, houve quatro candidatos não eleitos no Maranhão. No interior desse grupo estava Henrique Maximiano Coelho Neto (1864-1934). Em tal ano, esse escritor não conseguiu o apoio do partido governista daquele estado para se reeleger deputado federal. Por consequência, lançou-se como candidato independente e foi derrotado. Nessa ocasião, ele obteve 1.230 votos, os quais the conferiram a nona colocação no pleito. ${ }^{52}$ Em suma, a desvinculação de Coelho Neto do grupo governista de seu estado natal ocasionou a perda da base eleitoral por meio da qual desenvolvera sua carreira parlamentar. ${ }^{53}$

Tal situação foi análoga a dos candidatos de oposição pelo Paraná em 1918. Assim, o afastamento de Randolfo Serzedelo do grupo governista determinou o fim de suas chances de obter um novo mandato em uma instituição legislativa. O outro candidato de oposição a deputado federal pelo Paraná em 1918, o jornalista Leôncio Correia, experimentou sucessivas derrotas eleitorais após ter se afastado do situacionismo estadual. ${ }^{54}$ Nesse âmbito, era a abertura da vaga do terço que possibilitava o retorno momentâneo de governistas decaídos às instâncias do Poder Legislativo.

\section{Considerações finais}

Os resultados obtidos no decorrer deste artigo permitem a elaboração de três asserções. Primeiro, cabe reconhecer que os fenômenos da história política do Paraná estudados neste artigo não se revestem de um aspecto localista. Ao contrário, eles estão enquadrados em um cenário mais amplo. Esse cenário era composto pelos estados que compunham as pequenas bancadas da Câmara dos Deputados. Formados por apenas um distrito eleitoral, tais estados, nos anos 1910, tinham uma vida eleitoral desprovida do embate entre duas chapas completas de candidatos a deputado federal. Tal informação permite salientar que, de modo análogo ao Paraná, havia estados que não possuíam partidos de oposição suficientemente organizados para suplantar, em sua totalidade, os candidatos de uma chapa governista.

O segundo argumento afirma que era pouco consistente a organização interna dos partidos de oposição que surgiram no Paraná no fim dos anos 1910. Por consequência, essas

\footnotetext{
52 BRASIL. Anais da Câmara dos Deputados. Vol. 1. Rio de Janeiro: Imprensa Nacional, 1919, p. 359.

${ }^{53} \mathrm{Em} \mathrm{1915}$, ligado aos governistas do Maranhão, Coelho Neto se elegeu deputado federal com 9.862 votos. Ele obteve a sétima colocação nessa disputa. BRASIL. Anais da Câmara dos Deputados. Vol. 2. Rio de Janeiro: Imprensa Nacional, 1916, p. 41.

${ }^{54}$ Leôncio Correia malogrou em duas eleições para deputado federal, ocorridas em 1912 e 1918, e em uma eleição para o cargo de senador, realizada em 1909.
} 
agremiações não conseguiram formar uma ampla base eleitoral, bem como não tiveram a sua legitimidade reconhecida pela totalidade dos membros do campo oposicionista. Nesse cenário, não era incomum que houvesse o lançamento de candidaturas avulsas por indivíduos que não foram absorvidos aos quadros da grei oposicionista.

O terceiro argumento, por fim, salienta que a dificuldade de formar uma sólida base de apoiadores e fundar partidos internamente organizados tornava a oposição paranaense pouco competitiva do ponto de vista eleitoral. Os oposicionistas conseguiam ter acesso aos cargos legislativos, notadamente o de deputado federal, somente nas ocasiões em que os situacionistas formavam chapas incompletas de candidatos. Portanto, eles eram dependentes da concessão das vagas do terço realizada ocasionalmente pelos seus contendores. No Paraná, no fim dos anos 1910, os situacionistas determinavam os limites da presença da oposição em instâncias do Poder Legislativo. 


\section{Referências Bibliográficas}

ABREU, Alzira Alves de (coord.). Dicionário histórico-biográfico da Primeira República (1889-1930). Rio de Janeiro: Ed. da FGV, 2015.

ANTONACCI, Maria Antonieta. RS, as oposições e a Revolução de 23. Porto Alegre: Mercado Aberto, 1981.

CASALECCHI, José Ênio. O Partido Republicano Paulista: política e poder (1889-1926). São Paulo: Brasiliense, 1987.

COSTA, Luiz Domingos; MASSIMO, Lucas; PERISSINOTTO, Renato Monsseff. Oligarquia Competitiva e Profissionalização Política: O Caso dos Senadores Brasileiros na Primeira República (1889-1934). Dados, Rio de Janeiro, v. 60, n. 1, p. 79-110, 2017.

DAHL, Robert. Poliarquia. Trad.: Celso Mauro Paciornik. São Paulo: Edusp, 1997.

DANTAS, José Ibarê. Os partidos políticos em Sergipe, 1889-1964. Rio de Janeiro: Tempo Brasileiro, 1989.

FIGUEIREDO, Vítor Fonseca. Voto e competição política na Primeira República: o caso de Minas Gerais. 2016. Tese (Doutorado em História) - Instituto de Ciências Humanas, Universidade Federal de Juiz de Fora, Juiz de Fora.

GOULART, Mônica Helena Harrich Silva. Classe dominante e jogo político na Assembleia Legislativa Paranaense (1889-1930). 2008. Tese (Doutorado em Sociologia) - Setor de Ciências Humanas, Letras e Artes, Universidade Federal do Paraná, Curitiba.

HOLLANDA, Cristina Buarque de. Modos de representação política na Primeira República. Belo Horizonte: Ed. UFMG, 2009.

LESSA, Renato. A invenção republicana: Campos Sales, as bases e a decadência da Primeira República. Rio de Janeiro: Vértice, 1988.

MASSIMO, Lucas. A profissionalização da oligarquia no Brasil: um estudo sobre a estrutura da carreira política de senadores na Primeira República. 2018. Tese (Doutorado em Ciência Política) - Setor de Ciências Humanas, Letras e Artes, Universidade Federal do Paraná, Curitiba.

MONTENEGRO, Abelardo. Os partidos políticos no Ceará. Fortaleza: Ed. da UFC, 1980.

PINTO, Surama Conde Sá. Só para iniciados: o jogo político na antiga capital federal. Rio de Janeiro: Mauad, 2011.

PORTO, Walter Costa. A mentirosa urna. São Paulo: Martins Fontes, 2004.

PORTO, Walter Costa. O voto no Brasil: da Colônia à 6a República. Rio de Janeiro: Topbooks, 2002.

PRADO, Maria Lígia Coelho. A democracia ilustrada: o Partido Democrático de São Paulo, 1926-1934. São Paulo: Ática, 1986.

RESENDE, Maria Lage de. Formação da Estrutura de Dominação em Minas Gerais: o novo PRM (18891906). Belo Horizonte: Ed. UFMG/Proed, 1982. 
RICCI, Paolo; ZULINI, Jaqueline Porto. As eleições no Brasil republicano: para além do estereótipo da fraude eleitoral. História (São Paulo), Franca, v. 63, p. 48-58, 2015.

VISCARDI, Cláudia Maria Ribeiro. O Teatro das Oligarquias: uma revisão da política do "café com leite". Belo Horizonte: Fino Traço, 2012. 